\title{
Are Go-Jek Services Really Safe? Developing a Perceived Risk Scale
}

\author{
Ariyana Isti Kusumayani ${ }^{\mathrm{a}}$, Lavenda Geshica ${ }^{\mathrm{b}}$, Arlianto $^{\mathrm{c}}$, Dwi Cahyo Nugroho ${ }^{\mathrm{d}}$, \\ and Avin Fadilla Helmi ${ }^{\mathrm{e}}$
}

${ }^{a_{F a c u l t y}}$ of Psychology, Universitas Gadjah Mada, Yogyakarta, Indonesia; ${ }^{b_{F}}$ aculty of Psychology, Universitas Gadjah Mada, Yogyakarta, Indonesia; ${ }^{c}$ Faculty of Psychology, Universitas Gadjah Mada, Yogyakarta, Indonesia; ${ }_{\text {Faculty of Psychology, Universitas }}$ Gadjah Mada, Yogyakarta, Indonesia; ${ }^{e}$ Faculty of Psychology, Universitas Gadjah Mada, Yogyakarta, Indonesia

*Corresponding author:

Ariyana Isti Kusumayani

Faculty of Psychology

Universitas Gadjah Mada

J1. Sosio Humaniora Bulaksumur

Yogyakarta 55281 - Indonesia

Tel.: +62 274550435

Email address: ariyanaisti@gmail.com 


\title{
Are Go-Jek Services Really Safe? Developing a Perceived Risk Scale
}

\begin{abstract}
The primary objective of this research was the development of a scale to measure perceived risk among Go-Jek service (Go-Ride and Go-Car) customers. Non-probability sampling (convenience sampling) was used to select 145 participants (30 men, 115 women) from the population. All participants were Go-Jek customers living in Special Region of Yogyakarta. Perceived risk was measured using a modified version of the 18-item scale of Perceived Risk in Generic Drugs, developed by Suplet et al. The scale consisted of four parts: safety risk, financial risk, time risk, and social risk. The results of the analysis reveal a discrimination index ranging from 0.374 to 0.702 . Reliability, using the alpha coefficient, was 0.888 . The results of CFA gave a CMIN/df value of 1.333; a GFI value of 0.907 , a CFI value of 0.966 , and a RMSEA value of 0.048 . From these results it can be concluded that this model met the requirement of goodness of fit. The norm of this scale consisted of three categories: high perceived risk $(>36.8)$, moderate perceived risk $(15.8-36.8)$, and low perceived risk $(<15.8)$. The scale of perceived risk of Go-Jek services showed good reliability, validity, and discrimination index, making it a promising tool for assessing perceived risk of Go-Jek services.
\end{abstract}

Keywords: Go-Jek, perceived risk, scale, Yogyakarta

\section{Introduction}

Technological development has prompted many changes to modern life. In the field of public transportation, technology has brought about a new era of online transportation. This phenomenon is represented by a growing interest in using online transportation and, in Indonesia, the emergence, in 2010, of the country's first online transportation company. The company, called "PT. Aplikasi Karya Anak Bangsa", is better known as "Go-Jek" and was established in Jakarta by the entrepreneur Nadiem Makarim.

Since its inception, Go-Jek has become popular in big cities across Indonesia. Its success is similar to online transportation companies from other countries, some of which, such as Uber (in August 2014) and Grab (in June 2015), have tried to expand their business into Indonesia (CNN Indonesia, 2016). Moreover, local online transportation companies, such as Yellow-Jek, Jeger Taksi, TopJek, TeknoJek, PRO-JEK, Bojek, Bang-Jek, Ojek ARGO have also entered into the online transportation business in Indonesia.

Despite growing competition, Go-Jek retains the largest market share in the country. In March 2017, Go-Jek had 250,000 drivers and, 8 months later, in November 2017, that number had tripled to more than 850,000 (Noviansyah, 2017). The Go-Jek mobile application has been downloaded more than 40 million times (Irwin, 2017) and Go-Jek currently operates in more than 50 Indonesian cities, including Jakarta, Yogyakarta, Bandung, Surabaya, Makassar, Bali, and Palembang (Go-Jek, 2018). 
The popularity of Go-Jek is related to the advantages it offers its customers. First, drivers and customers can accurately locate each other via a built-in GPS in the Go-Jek mobile application. Second, the fare is relatively affordable and fixed, so that it is not subject to change once it has been agreed. Third, customers can order the service through the mobile application at any time. Fourth, it is relatively convenient compared to other public transport options. Finally, through the application, Go-Jek customers can acquire important information about the driver and vehicle they will use.

Despite these advantages, Go-Jek suffers from several major problems, leading to customer distrust and insecurity. These problems are primarily related to taxis and ojeks (motorcycle taxis). Competition between Go-Jek and conventional public transportation (taxi and ojek) has led to large public demonstrations and conflict (Birra, 2017). There have also been concerns about customer safety when using Go-Jek services. In February 2018, a driver sexually assaulted a passenger, and there have been incidences of drivers intimidating customers who had previously given drivers bad ratings on the mobile application (Gunawan, 2017; Amelia, 2018). Some Go-Jek drivers have been found to send inappropriate messages to customers who have used promotions from the Go-Jek application to get discounted fares (Ramlan, 2017). These issues of intimidation and violence have the potential to create insecurity among customers, and some may perceive multiple risks to using Go-Jek services.

Stone and Grǿnhaug (1993) define perceived risk as "subjective expectations of loss; the more certain one is of this loss, the greater the risk perceived by the individual". To evaluate perceived risk among Go-Jek (Go-Ride and Go-Car) customers, a scale to measure perceived risk among these customers' needs to be developed. Although perceived risk scales have been used in the fields of online shopping, generic drugs, and online payments (Suplet et al., 2009; Thakur \& Srivastava, 2015; Yang et al., 2015), no scale aimed specifically at perceived risks related to online transportation have been developed. In addition, given that psychological measurement is culturally specific, no scale exists to measure perceived risk of Go-Jek services in the context of Indonesia.

\section{Methods}

\section{Participants}

A total of 145 Go-Ride and Go-Car customers living in Special Region of Yogyakarta were recruited for this survey. Non-probability sampling (convenience sampling) was used to ensure a representative sample of participants from the population.

Table I. Blueprint

\begin{tabular}{|l|l|l|l|}
\hline No & \multicolumn{1}{|c|}{ Aspect } & \multicolumn{1}{|c|}{ Conceptual Definition } & \multicolumn{1}{|c|}{ Items No } \\
\hline 1 & Social risk & $\begin{array}{l}\text { a risk that made customer feel shame and lose social } \\
\text { status due to the purchase }\end{array}$ & $1,2,3$ \\
\hline 2 & Time risk & time limitation of product satisfying customer's needs & $4,5,6$ \\
\hline 3 & Financial risk & $\begin{array}{l}\text { a loss caused by incorrect allocation of money and } \\
\text { price discrepancies with products }\end{array}$ & $7,8,9$ \\
\hline 4 & Physical risk & a risk related to health and safety & $10,11,12$ \\
\hline
\end{tabular}




\begin{tabular}{|l|l|l|l|}
\hline 5 & Functional risk & $\begin{array}{l}\text { a frequent loss occurred when the product did not } \\
\text { work as expected }\end{array}$ & $13,14,15$ \\
\hline 6 & Psychological risk & $\begin{array}{l}\text { a risk related to how product consumption might } \\
\text { disturb customer's sense of self or a certain perception } \\
\text { of self }\end{array}$ & $16,17,18$ \\
\hline
\end{tabular}

\section{Procedure}

First, the perceived risk of generic drugs scale, developed by Suplet et al. (2009), was modified. That scale consisted of six aspects: social risk, time risk, financial risk, physical risk, functional risk, and psychological risk. Social risk is defined as a risk that makes a customer feel shame or lose social status due to a purchase. Time risk is the time limitation for which a product satisfies the customer's needs. Financial risk is a loss caused by incorrect allocation of money and price discrepancies between similar products. Physical risk is a risk related to health and safety. Functional risk is a loss that occurs when a product does not work as expected. Psychological risk is a risk related to how product consumption disturbs the customer's sense of self or a particular perception of self. Each aspect consists of three items, resulting in a modified scale of 18 items.

Second, item analysis, using data from the research sample, was conducted. An internal consistency formula (alpha coefficient) was used to estimate scale reliability and item discrimination. According to Wells and Wollack (in Azwar, 2017a), the minimum value of internal consistency is between 0.80 and 0.85 .

Third, exploratory factor analysis (EFA) and confirmatory factor analysis (CFA) were carried out to create a model of perceived risk of Go-Jek services. EFA played a significant role in recognizing and identifying the various factors making up each construct (Azwar, 2017b). EFA had three steps. First, if data met EFA assumptions, the total variance value could be explained. Second, after finding factors that represented constructs, these items were grouped and the content of each item reviewed. This step allowed for the labeling of each item. Third, CFA was carried out to ensure factor suitability between EFA and raw data. AMOS 16 was used to examine the measurement model.

\section{Results}

\section{Item Discrimination Index Analysis}

Corrected-item total correlation was used to analyze the item discrimination index. A limit of more than or equal 3.0 was set. This analysis proved that all scale items had a good item discrimination index ranging from 0.374 to 0.702 .

\section{Scale Reliability}

A reliability analysis was carried out by employing the single trial administration approach using the alpha coefficient. From this analysis, it was observed that this modified perceived risk scale had good reliability $(\alpha=0.888$ ). Therefore, it was concluded that $89 \%$ variance from the observed score was variance from the true score, and $12 \%$ variance from the observed score was variance due to error. 


\section{Exploratory Factor Analysis}

Data analysis proved that this modified scale had a KMO value of more than $0.5(0.843>0.5)$. As shown in Table II, variables could be represented by four components.

Table II. Item Distribution Based on Explanatory Factor Analysis

\begin{tabular}{|l|l|l|l|}
\hline Factor 1 & Factor 2 & Factor 3 & Factor 4 \\
\hline Item 10 & Item 8 & Item 4 & Item 1 \\
\hline Item 11 & Item 9 & Item 5 & Item 2 \\
\hline Item 12 & Item 15 & Item 6 & Item 3 \\
\hline Item 13 & Item 18 & Item 7 & \\
\hline Item 14 & & & \\
\hline Item 16 & & & \\
\hline Item 17 & & & \\
\hline
\end{tabular}

The sum of these four factors explains $60.875 \%$ of the construct. The results of the analysis demonstrate that the 18-item perceived risk scale can be categorized into four factors (see Table I). This differs from the original conceptualization of the scale, which contained six factors. After grouping factors and analyzing item content, it was concluded that the highest factor was safety risk, the second highest was financial risk, the third time risk, and the fourth social risk.

\section{Confirmatory Factor Analysis}

The result of standardized regression weight estimation for each item from the CFA (Table III) shows that each item's measured latent variable of perceived risk had an adequate loading factor $(>0.5)$. Item 7 is not included in the table because its factor loading was $<0.5$.

Table III. Standardized Regression Weights

\begin{tabular}{|l|l|l|l|}
\hline \multicolumn{5}{|c|}{ Estimate } \\
\hline Item_6 & $<---$ & F3 & 0,749 \\
\hline Item_5 & $<---$ & F3 & 0,93 \\
\hline Item_4 & $<---$ & F3 & 0,703 \\
\hline Item_3 & $<---$ & F4 & 0,795 \\
\hline Item_2 & $<---$ & F4 & 0,664 \\
\hline Item_1 & $<---$ & F4 & 0,671 \\
\hline Item_8 & $<---$ & F2 & 0,738 \\
\hline Item_9 & $<---$ & F2 & 0,695 \\
\hline Item_15 & $<---$ & F2 & 0,677 \\
\hline Item_18 & $<---$ & F2 & 0,691 \\
\hline Item_10 & $<---$ & F1 & 0,599 \\
\hline Item_11 & $<---$ & F1 & 0,748 \\
\hline Item_12 & $<---$ & F1 & 0,788 \\
\hline Item_13 & $<---$ & F1 & 0,83 \\
\hline Item_14 & $<---$ & F1 & 0,818 \\
\hline Item_16 & $<---$ & F1 & 0,527 \\
\hline Item_17 & $<---$ & F1 & 0,539 \\
\hline
\end{tabular}


The CFA model fit was based on Kline (2011), necessitating the reporting of three components: Chi-square $\left(\chi^{2}\right), p$ value, and RMSEA. In addition, the reporting of CFI and RMR data are recommended. The requirements of fit criteria were small values of Chi-square $\left(\chi^{2}\right), p \geq 0,05$; RMSEA $\leq 0,05 ; \mathrm{CFI} \geq 0,90$; and CMIN $\leq 1,5$. From these results, the value of CMIN/df was found to be 1.331 , the GFI value 0,907 , the CFI value 0.966 , and the RMSEA value 0.048 . Therefore, the CFA model that followed modification indices showed the results had met the requirements of goodness of fit.

\section{Norming}

To determine the norm of this scale, it was decided to divide the score into three groups, namely high perceived risk (> 36.8), moderate perceived risk (15.8 to 36.8), and low perceived risk $(<15.8)$.

\section{Discussion}

The aim of this research was to develop a scale to measure perceived risk among Go-Jek (GoRide and Go-Car) service customers. This scale was a modified version of the customer perception of perceived risk in generic drugs scale developed by Suplet et al (2009). There are some important differences between the original perceived risk scale (perceived risk in generic drugs) and the modified version (perceived risk among Go-Jek service customers). The original version consisted of six factors, whereas the modified version has four factors. These factors were obtained by EFA.

Safety risk was found to be a combination of physical risk and psychological risk. The amalgamation of these items was based on items within financial risk and psychological risk that related to participants' safety as Go-Jek customers. In addition, it was assumed that participants considered physical and psychological aspects together and these could not be viewed separately. Therefore, both physical and psychological aspects were crucial to a customer's sense of security.

Functional risk, as in the original perceived risk scale developed by Suplet et al (2009), was merged into financial and safety risk. Items 13 and 14 in financial risk were also elements of safety risk. However, Item 15 (I am worried that I will not get the promised benefits while using Go-Ride or Go-Car) was moved into financial risk. It was assumed, therefore, that participants believed that online transportation functioned well if it was safe and commensurate with the amount of money spent.

The seventh item of the modified version scale (I am worried that the service provided by GoRide or Go-Car does not equate with the price) was excluded because it had a loading factor of less than 0.5 . This may be the result of the online procedure for ordering a Go-Jek vehicle, as the application shows the amount of money that customers must pay, meaning that customers only use the service if the fare is agreeable to them. 


\section{Conclusion and Limitations}

This research produced a 17-item scale of perceived risk of Go-Jek services (Go-Ride and GoCar). It consisted of four factors: safety risk, financial risk, time risk, and social risk. This modified scale had an adequate discrimination index, and adequate reliability and validity. Therefore, if offers promise as a tool to measure the perceived risk to Go-Jek customers. The level of perceived risk of participants in this study could be determined by referring to their final score. A customer with a score of more than 36.8 had high perceived risk, a score between 15.6 and 36.8 indicated moderate perceived risk, and a score of less than 15.8 indicated low perceived risk.

This research had a number of limitations. The first of these was the small sample size of only 145 participants. It is recommended that future research should use a larger sample in order to meet the assumptions of normal distribution. In addition, this research did not calculate external validity, and future research should calculate this using a consumer satisfaction scale or other relevant scales.

Finally, it is advised that interviews be conducted with those participants who were found to have the lowest and the highest perceived risk in order to acquire more comprehensive data concerning the perceived risks of Go-Jek customers. In spite of these limitations, this scale can also be used by Go-Jek to evaluate its own services related to customer risk perception. Such an evaluation is important to ensure customer satisfaction and loyalty.

\section{References}

Amelia, M. (2018). Pelaku pelecehan penumpang taksi online pakai akun mitra Go-Jek. Retrieved from https://news.detik.com/berita/d-3865879/pelaku-pelecehan-penumpang-taksi-onlinepakai-akun-mitrago-jek

Azwar, S. (2017a). Penyusunan skala psikologi. Yogyakarta: Pustaka Pelajar.

Azwar, S. (2017b). Reliabilitas dan validitas. Yogyakarta: Pustaka Pelajar.

Birra, F. A. (2017). Kisruh angkutan online dan konvensional berbuntut panjang. Retrieved from https://www.jawapos.com/teknologi/31/12/2017/kisruh-angkutan-online-dankonvensional-berbuntutpanjang

CNN Indonesia. (2016). Anthony Tan, Pendiri Grab yang Mendukung dan Menggoyang Taksi. Retrieved from https://www.cnnindonesia.com/teknologi/20160314152202-185-117313/anthony-tan-pendiri-grabyang-mendukung-dan-menggoyang-taksi

Go-jek. (2018). Satu aplikasi untuk semua kebutuhan anda. Retrieved from https://www.go-jek.com/about/10

Gunawan, D. (2017). Pengguna Go-Jek diteror setelah memberikan bad review. Retrieved from https://id.techinasia.com/talk/pengguna-go-jek-diteror-setelah-memberikan-badreview

Irwin, P. (2017). Aplikasi Go-Jek Tembus 40 Juta Pengunduh. Retrieved from https://www.wartaekonomi.co.id/read144364/aplikasi-gojek-tembus-40-juta-pengunduh.html

Matsumoto, D. R. \& Juang, L. P. (2013). Culture and psychology. Belmont, CA: Wadsworth Cengage Learning.

Noviansyah, A. (2017). Go-Jek kini punya 850.000 mitra driver. Retrieved from https://kumparan.com/@kumparantech/go-jek-kini-punya-850-000-mitra-driver

Ramlan, O. (2017). Gara-gara pakai promo aplikasi, penumpang ojek online ini malah dapat chat tidak senonoh dari driver. Retrieved from https://chirpstory.com/li/356882 
Stone, R. N. \& Grønhaug, K. (1993). Perceived risk: further considerations for the marketing discipline. European Journal of Marketing, 27(3), 39-50.

Suplet, M. R., Suárez, M. G., \& Díaz, A. M. (2009). Customer perceptions of perceived risk in generic drugs: The Spanish market. Innovar, 19(34), 53-64.

Thakur, R., \& Srivastava, M. (2015). A study on the impact of consumer risk perception and innovativeness on online shopping in India. International Journal of Retail \& Distribution Management, 43(2), 148-166.

Yang, Q., Pang, C., Liu, L., Yen, D. C., \& Michael, T. J. (2015). Exploring consumer perceived risk and trust for online payments: An empirical study in China's younger generation. Computers in Human Behavior, 50, 9-24. 